\title{
Research on Non-Timber Forest Products in Selected Countries in Southern and East Africa: Themes, Research Issues, Priorities and Constraints
}

\author{
M. Ruiz Pérez', A.J. Broekhoven², J.R.W. Aluma, S. Iddi', J.D. Lowore, \\ S.M. Mutemwa ${ }^{6}$ and J.A. Odera
}

\begin{abstract}
Summary
In this paper, the outcomes of a consultative meeting on non-timber forest products are reported and discussed. The meeting was organised by CIFOR and IUCN's Eastern Africa Regional Office on 15 and 16 September 1995 in Nairobi, Kenya, with the aim of discussing research priorities and information gaps related to non-timber forest products. The workshop brought together 11 people, representing forest research institutions, NGOs and other organisations involved in research related to non-timber forest products. The countries represented were Malawi, Kenya, Tanzania, Uganda and Zambia. During the meeting priority themes and issues were identified. These relate to management systems, policy and institutions, and community roles and social dimensions. Priority constraints include lack of personnel with appropriate expertise, inadequate financial resources, and insufficient data and information. A large number of solutions to overcome these constraints was discussed.

It is concluded that since the main relevance of non-timber forest products in Southern and East Africa is at the local and subsistence level, an elaboration of the results of the meeting into workable research questions and methods should be defined at that level in an iterative process of action research, involving researchers and local users and managers of the forest.

The meeting can be considered as a first, though authoritative, approximation of the needs in research on non-timber forest products in the region. It was agreed that elaboration of the findings of the meeting into specific action would be the only useful next step.
\end{abstract}

1 Center for International Forestry Research (CIFOR), P.O. Box 6596, JKPWB, Jakarta 10065, Indonesia

2 IUCN Eastern Africa Regional Office (EARO), P.O. Box 68200, Nairobi, Kenya

3 Forestry Research Institute, P.O. Box 1752, Kampala, Uganda

4 Present address: Forest and Beekeeping Division, P.O. Box 426, Dar-es-Salaam, Tanzania

5 Forestry Research Institute of Malawi, P.O. Box 270, Zomba, Malawi

6 Division of Forest Products, Forestry Department, P.O. Box 20388, Kitwe, Zambia

7 Kenya Forestry Research Institute, P.O. Box 20412, Nairobi, Kenya 


\section{The CGIAR System}

The Consultative Group on International Agricultural Research (CGIAR) is an informal association of 41 public and private sector donors that supports a network of sixteen international agricultural research institutes, CIFOR being the newest of these. The Group was established in 1971. The CGIAR Centers are part of a global agricultural research system which endeavour to apply international scientific capacity to solution of the problems of the world's disadvantaged people.

\section{CIFOR}

CIFOR was established under the CGIAR system in response to global concerns about the social, environmental and economic consequences of loss and degradation of forests. It operates through a series of highly decentralised partnerships with key institutions and/or individuals throughout the developing and industrialised worlds. The nature and duration of these partnerships are determined by the specific research problems being addressed. This research agenda is under constant review and is subject to change as the partners recognise new opportunities and problems. 
CENTER FOR INTERNATIONAL FORESTRY RESEARCH

office address: Jalan CIFOR, Situ Gede, Sindangbarang, Bogor 16680, Indonesia mailing address: P.O. Box 6596 JKPWB, Jakarta 10065, Indonesia

tel.: +62 (251) 622622 fax: $+62(251) 622100$

email: cifor@cgnet.com

$W W W:$ http://www.cgiar.org/cifor 


\title{
Research on Non-Timber Forest Products in Selected Countries in Southern and East Africa: Themes, Research Issues, Priorities and Constraints
}

\author{
M. Ruiz Pérez, A.J. Broekhoven, J.R.W. Aluma, S. Iddi, J.D. Lowore, S.M. Mutemwa \\ and J.A. Odera
}

\begin{abstract}
Summary
In this paper, the outcomes of a consultative meeting on non-timber forest products are reported and discussed. The meeting was organised by CIFOR and IUCN's Eastern Africa Regional Office on 15 and 16 September 1995 in Nairobi, Kenya, with the aim of discussing research priorities and information gaps related to non-timber forest products. The workshop brought together 11 people, representing forest research institutions, NGOs and other organisations involved in research related to non-timber forest products. The countries represented were Malawi, Kenya, Tanzania, Uganda and Zambia. ${ }^{l}$ During the meeting priority themes and issues were identified. These relate to management systems, policy and institutions, and community roles and social dimensions. Priority constraints include lack of personnel with appropriate expertise, inadequate financial resources, and insufficient data and information. A large number of solutions to overcome these constraints was discussed.

It is concluded that since the main relevance of non-timber forest products in Southern and East Africa is at the local and subsistence level, an elaboration of the results of the meeting into workable research questions and methods should be defined at that level in an iterative process of action research, involving researchers and local users and managers of the forest.

The meeting can be considered as a first, though authoritative, approximation of the needs in research on nontimber forest products in the region. It was agreed that elaboration of the findings of the meeting into specific action would be the only useful next step.
\end{abstract}

\section{Introduction}

\section{Background}

Forests provide a large variety of products and offer diverse environmental services world-wide. However, after World War II, institutional attention focused on the production of timber, leaving aside non-timber forest products (NTFP) ${ }^{2}$ and most of the environmental functions. East and Southern Africa did not escape this trend, developing forest policies that focused on industrial roundwood plantations (Kowero 1990; Aluma 1995; Mutemwa 1995; Odera 1995). The restriction of access to plantations and other types of forest managed by government institutions frequently conflicted with customary law. Dwindling forest resources and increasing population pressures resulted in deprivation of key livelihood resources for rural populations (Mutemwa 1995; Odera 1995).

In the last fifteen years a growing interest in multiple use of forests has brought the issue of NTFP to the forefront of the research and development agenda. Hundreds of site-specific studies have been conducted (see Townson 1995 for an annotated bibliography) and a number of regional overviews have been produced (e.g., de Beer and McDermott 1989 for South-east

\footnotetext{
1 Table on area of forest and other wooded land in the countries represented is found in Annex II.

2 Discussions of the definition, categories and use of non-timber forest products can be found in several publications (e.g., de Beer and McDermott 1989; Falconer 1990; FAO 1995a). In this paper we will use the definition provided by Falconer (1990) as "any products, excluding commercially exploited timber, gathered from forests, whether for commercial or subsistence purposes".
} 
Asia; CATIE 1992 for Central America; Anderson 1990 and Lescure 1995 for the Amazon Region; Falconer 1990 for West Africa). Again, these winds of change have affected the region, with the new policies incorporating multi-functional, multi-purpose forest management regulations (Kenya Forestry Master Plan 1994; Aluma 1995; Lowore 1995; Odera 1995)

One of the key factors in this renewed attention has been the convergence of interests between development and conservation organisations. A commonly held view is that NTFP can offer options for improving people's livelihoods while at the same time helping to conserve the forest against some of the threats posed by alternative options (see Myers 1986; Allegretti 1989; Falconer and Arnold 1989; Fearnside 1989; Peters et al. 1989; Bennett 1992; Nepstad and Schwartzman 1992; Panayotou and Ashton 1992; Plotkin and Famolare 1992; Redford and Padoch 1992; Clay and Clement 1993; Ros-Tonen et al. 1995). This assumption is at the basis of several initiatives carried out by national and international institutions and NGOs such as FAO, IUCN, Cultural Survival, WWF and Conservation International. It should be remembered that the acceptance of this assumption is not unanimous and that a number of authors have pointed out some of its flaws as well as facts that remain to be proven (see Bodmer et al. 1988; Browder 1992; González 1992; Redford 1992; Redford and Stearman 1993; Conklin and Graham 1995; Peters 1996; Ruiz Pérez and Arnold 1996).

In this sense, both the Center for International Forestry Research (CIFOR) in Bogor, Indonesia, and the Forest Conservation Programme of IUCN see it as their role to facilitate further exploration of how the use of NTFP can contribute to forest conservation and sustainable forest management, spelling out the conditions that favour this contribution as well as the potential conflicts and obstacles.

A prerequisite to enhance the contribution of NTFP to forest conservation and sustainable management is research that provides bottom-line information and scientific assessment of this potential. Although detailed case studies have been conducted, overall views and thorough analyses are scarce. The so-called "fuelwood crisis" of the 70s and 80 s brought a number of country studies and triggered a process of plantations to meet the perceived future shortages (French 1986; Ministry of Natural Resources of Uganda
$1994)^{3}$. The potential of certain types of product, like medicinal plants, is being studied (see Cunningham 1993). Regional consultations for NTFP have been carried out by FAO and IUCN (Crafter et al. 1996) and overviews are being produced of some key regional forest ecosystems, such as the "miombo" (Campbell 1996) that provides livelihoods for millions of people. However, we are still far from a regional or even national picture that offers an inventory, diagnosis and action-guided proposals.

\section{Structure of the workshop and the paper}

Bearing in mind the need for a diagnosis of the research on NTFP currently being undertaken by National Research Institutes (NRIs) in different tropical regions, CIFOR commissioned IUCN's Eastern Africa Regional Office (EARO) to organise a consultative meeting. This was intended to assist both institutions to further develop their programmes of activities related to NTFP as well as to identify potential national partners for collaborative work. ${ }^{4}$

The meeting, which took place on 15-16 September 1995 in Nairobi, Kenya, brought together researchers from Kenya, Malawi, Tanzania, Uganda and Zambia. ${ }^{5}$ The participants represented national and international forest research organisations, NGOs and other agencies with an interest in forest conservation and management. The aim of the meeting was to identify research priorities and information gaps in relation to non-timber forest products and to enhance co-operation between the institutions involved in these issues.

This paper reports on and discusses the outcomes of the workshop.

The first section is based on background papers commissioned for the workshop and on discussions amongst the participants. This is followed by presentation of the main themes, research issues, and priorities and constraints for carrying out research related to non-timber forest products in selected countries in Southern and East Africa.

During the discussions, the participants were first asked to identify the main, over-arching research themes based on their lengthy experiences as researchers and research managers. Individual oral presentations were supplemented by a strong group interaction. Eight major themes were identified (see below).

\footnotetext{
${ }^{3}$ See Dewees 1989 for a critique of the "fuelwood crisis".

${ }^{4}$ Both the Center for International Forestry Research (CIFOR) in Bogor, Indonesia, and the Forest Conservation Programme of IUCN see it as their role to facilitate further exploration of how the use of non-timber forest products can contribute to forest conservation and sustainable forest management.

${ }^{5}$ See annex III for a list of participants.
} 
A number of general research issues were identified for each research theme. Each participant separately listed those issues relevant to him/her for each theme. This was followed by a group discussion in order to synthesise and merge the full list into a reduced number of distinct issues. Each of these was then assigned a priority (low, medium, high) by every participant. ${ }^{6}$ In order to avoid the initial tendency to assign a high priority to every issue, participants were asked to consider the exercise in the context of limited resources and an urgent need to develop action-oriented output. The results of the prioritisation were tabulated and discussed by the group.

Having completed this process for each theme, the next step was to identify the constraints. Identification of individual views was again followed by group discussions to clarify and merge the list into a number of distinct factors. Finally, participants were asked to propose solutions to the constraints. Both constraints and solutions were grouped under a number of general headings. Given the common problems experienced by most participants and their research centres it was felt that a group discussion about the solutions was more appropriate and enriching.

In the final part of the paper, the outcomes of this exercise are discussed and suggestions presented for follow-up actions.

\section{Research Themes, Issues, Priorities and Constraints}

\section{Research themes and issues}

Eight major research themes were identified by the group:

1) Markets and marketing

2) Resources management

3) Technology

4) Cultural values

5) Policy and institutional arrangements

6) Community roles and social dimensions

7) Research on methodologies

8) Valuation

All themes were considered equally important in order to understand the complexity of non-timber forest products and their management.

The research issues within each theme were formulated at a general level. Time restrictions and the fact that most participants were research managers rather than active researchers did not allow the process to continue to an operational level of definition. The research issues and their priorities are presented in Table 1.

Table 1. Priority ranking of research issues

\begin{tabular}{|c|c|c|c|c|c|}
\hline & \multicolumn{3}{|c|}{ Priority } & \multirow[b]{2}{*}{ Index } & \multirow[b]{2}{*}{ Rank (1-44) } \\
\hline & High & Medium & Low & & \\
\hline \multicolumn{6}{|l|}{ 1. THEME: MARKETS AND MARKETING } \\
\hline \multicolumn{6}{|l|}{ Research issues } \\
\hline 1.1 Effects on local communities, including different groups & 7 & 2 & 0 & 80 & $3 / 4$ \\
\hline 1.2 Market opportunities for current and new products & 7 & 1 & 1 & 76 & $5 / 6$ \\
\hline 1.3 Distribution of benefits & 5 & 3 & 1 & 66 & $14 / 18$ \\
\hline 1.4 Influence of markets on development of & & & & & \\
\hline non-timber products & 4 & 4 & 1 & 61 & $23 / 27$ \\
\hline 1.5 Marketing information & 4 & 2 & 3 & 53 & $34 / 35$ \\
\hline 1.6 Demand and supply of products marketed & 2 & 6 & 1 & 51 & 38 \\
\hline 1.7 Market organisation & 3 & 2 & 4 & 44 & 41 \\
\hline 1.8 Pricing mechanisms & 2 & 3 & 4 & 39 & $42 / 43$ \\
\hline \multicolumn{6}{|l|}{ 2. THEME: RESOURCES MANAGEMENT } \\
\hline \multicolumn{6}{|l|}{ Research issues } \\
\hline 2.1 Management systems and the roles of different groups & 8 & 1 & 0 & 85 & $1 / 2$ \\
\hline 2.2 Tenure and access rights & 5 & 4 & 0 & 70 & $11 / 13$ \\
\hline 2.3 Ecological implications of harvesting & 5 & 3 & 1 & 66 & $14 / 18$ \\
\hline 2.4 Extraction rates: growth and yield & 4 & 3 & 2 & 57 & $31 / 32$ \\
\hline 2.5 Biological possibilities for increasing production & 3 & 4 & 2 & 52 & $36 / 37$ \\
\hline
\end{tabular}

\footnotetext{
${ }^{6}$ Nine workshop participants took part in the ranking exercise.
} 
Table 1 continued

\begin{tabular}{|c|c|c|c|c|c|}
\hline & \multicolumn{3}{|c|}{ Priority } & \multirow[b]{2}{*}{ Index } & \multirow[b]{2}{*}{ Rank (1-44) } \\
\hline & High & Medium & Low & & \\
\hline \multicolumn{6}{|l|}{ 3. THEME: TECHNOLOGY } \\
\hline \multicolumn{6}{|l|}{ Research issues } \\
\hline 3.1 Potential for development of small scale, local industry & 6 & 3 & 0 & 75 & 7 \\
\hline 3.2 Inventory of technologies & 5 & 4 & 0 & 70 & $11 / 13$ \\
\hline 3.3 Product harvesting, processing and storage & 4 & 4 & 1 & 61 & $23 / 27$ \\
\hline 3.4 Product development potentials & 5 & 1 & 3 & 58 & $29 / 30$ \\
\hline 3.5 Impact of technological changes & 3 & 5 & 1 & 46 & 40 \\
\hline \multicolumn{6}{|l|}{ 4. THEME: CULTURAL VALUES } \\
\hline \multicolumn{6}{|l|}{ Research issues } \\
\hline 4.1 Identification of values & 5 & 3 & 1 & 66 & $14 / 18$ \\
\hline 4.2 Cultural constraints/opportunities for the & 1 & 1 & 1 & 61 & $23 / 27$ \\
\hline 4.3 Conflicts between cultural values and existing & 4 & 4 & 1 & 01 & 201 \\
\hline management systems & 3 & 4 & 2 & 52 & $36 / 37$ \\
\hline 4.4 Role of religious beliefs & 2 & 3 & 4 & 39 & $42 / 43$ \\
\hline 4.5 Impact of changing values & 1 & 4 & 4 & 34 & 44 \\
\hline \multicolumn{6}{|l|}{ 5. THEME: POLICIES AND INSTITUTIONAL ARRANGEMENTS } \\
\hline \multicolumn{6}{|l|}{ Research issues } \\
\hline 5.1 Effects of past and existing natural resource policies & 7 & 1 & 1 & 76 & $5 / 6$ \\
\hline 5.2 Effects of external policies on traditional institutions & 6 & 2 & 1 & 71 & $8 / 10$ \\
\hline 5.3 De facto and de jure ownership and user rights & 4 & 5 & 0 & 65 & $19 / 20$ \\
\hline 5.4 Institutional framework, including inter-sectoral linkages & 5 & 2 & 2 & 62 & $21 / 22$ \\
\hline 5.5 Incentives & 4 & 4 & 1 & 61 & $23 / 27$ \\
\hline 5.6 Impact of commercialisation at all level & 3 & 6 & 0 & 60 & 28 \\
\hline \multicolumn{6}{|l|}{ 6. THEME: COMMUNITY ROLES AND SOCIAL DIMENSIONS } \\
\hline \multicolumn{6}{|l|}{ Research issues } \\
\hline 6.1 Participatory/joint management & 8 & 1 & 0 & 85 & $1 / 2$ \\
\hline 6.2 Dependence of different groups on non-timber forest products & 7 & 2 & 0 & 80 & $3 / 4$ \\
\hline 6.3 Distribution of benefits & 5 & 3 & 1 & 66 & $14 / 18$ \\
\hline 6.4 Role of individuals, households and communities & 5 & 3 & 1 & 66 & $14 / 18$ \\
\hline 6.5 Relations between different groups & 4 & 4 & 1 & 61 & $23 / 27$ \\
\hline 6.6 Population dynamics & 4 & 2 & 3 & 53 & $34 / 35$ \\
\hline 6.7 Attitudes and social change & 3 & 3 & 3 & 48 & 39 \\
\hline \multicolumn{6}{|l|}{ 7. THEME: RESEARCH ON METHODOLOGIES } \\
\hline \multicolumn{6}{|l|}{ Research issues } \\
\hline 7.1 Standardisation of methodologies & 6 & 2 & 1 & 71 & $8 / 10$ \\
\hline 7.2 Development of participatory methods & 6 & 2 & 1 & 71 & $8 / 10$ \\
\hline 7.3 Multi-resource inventory & 5 & 2 & 2 & 62 & $21 / 22$ \\
\hline 7.4 Classification of products and units of measurement & 4 & 3 & 2 & 57 & $31 / 32$ \\
\hline \multicolumn{6}{|l|}{ 8. THEME: VALUATION } \\
\hline \multicolumn{6}{|l|}{ Research issues } \\
\hline $\begin{array}{l}\text { 8.1 Criteria/parameters for market and non-market values of } \\
\text { non-timber forest products }\end{array}$ & 5 & 4 & 0 & 70 & $11 / 13$ \\
\hline 8.2 Economic contribution at all levels & 4 & 5 & 0 & 65 & $19 / 20$ \\
\hline 8.3 Cost-benefit analysis & 5 & 1 & 3 & 58 & $29 / 30$ \\
\hline $\begin{array}{l}8.4 \text { Maximising and realising value of non-timber forest } \\
\text { products (emphasis on local value) }\end{array}$ & 3 & 5 & 1 & 56 & 33 \\
\hline
\end{tabular}


Table 2. Research issues with a high priority

\begin{tabular}{|c|c|c|}
\hline \multicolumn{2}{|l|}{ Issues } & Priority index (\%) \\
\hline $2.1 \quad$ Management systems and roles of different groups & 94 \\
\hline 6.1 & Participatory/joint management & 94 \\
\hline 1.1 & Effects of markets on local communities & 89 \\
\hline 6.2 & Dependence of different groups on non-timber forest products & 89 \\
\hline 1.2 & Market opportunities for current and new products & 84 \\
\hline 5.1 & Effects of past and existing natural resource policies & 84 \\
\hline 3.1 & Potential for development of small-scale industry & 83 \\
\hline 5.2 & Effects of external policies on traditional institutions & 79 \\
\hline 7.1 & Standardisation of methodologies & 79 \\
\hline 7.2 & Development of participatory methods & 79 \\
\hline
\end{tabular}

It should be emphasised that the research issues are not completely independent or self-contained. On the contrary, there are strong links between some issues that arise in different themes, as there are indeed between the eight themes identified.

\section{Priority research themes and issues}

A priority index was calculated by giving a value of 10 to high priority, 5 to medium priority and 1 to low priority. The maximum possible value for the 9 responses is 90 . The priority index is the percentage of this maximum theoretical value. Table 2 shows the ten research issues which were given the highest priority. These ten issues, $22.7 \%$ of the total of 44 research issues identified, were allocated a high ranking by six or more participants.

As has already been noted, the eight main research themes were initially considered of equal importance for a comprehensive understanding of the potential of non-timber forest products and therefore were not prioritised. However, the index used for the issues can also be used as a proxy to identify the combined importance assigned by the group to each of the themes. Thus an average index was calculated by adding the total score for a given theme and dividing it by the number of issues. Figure 1 ranks the eight main themes according to the average importance of their research issues.

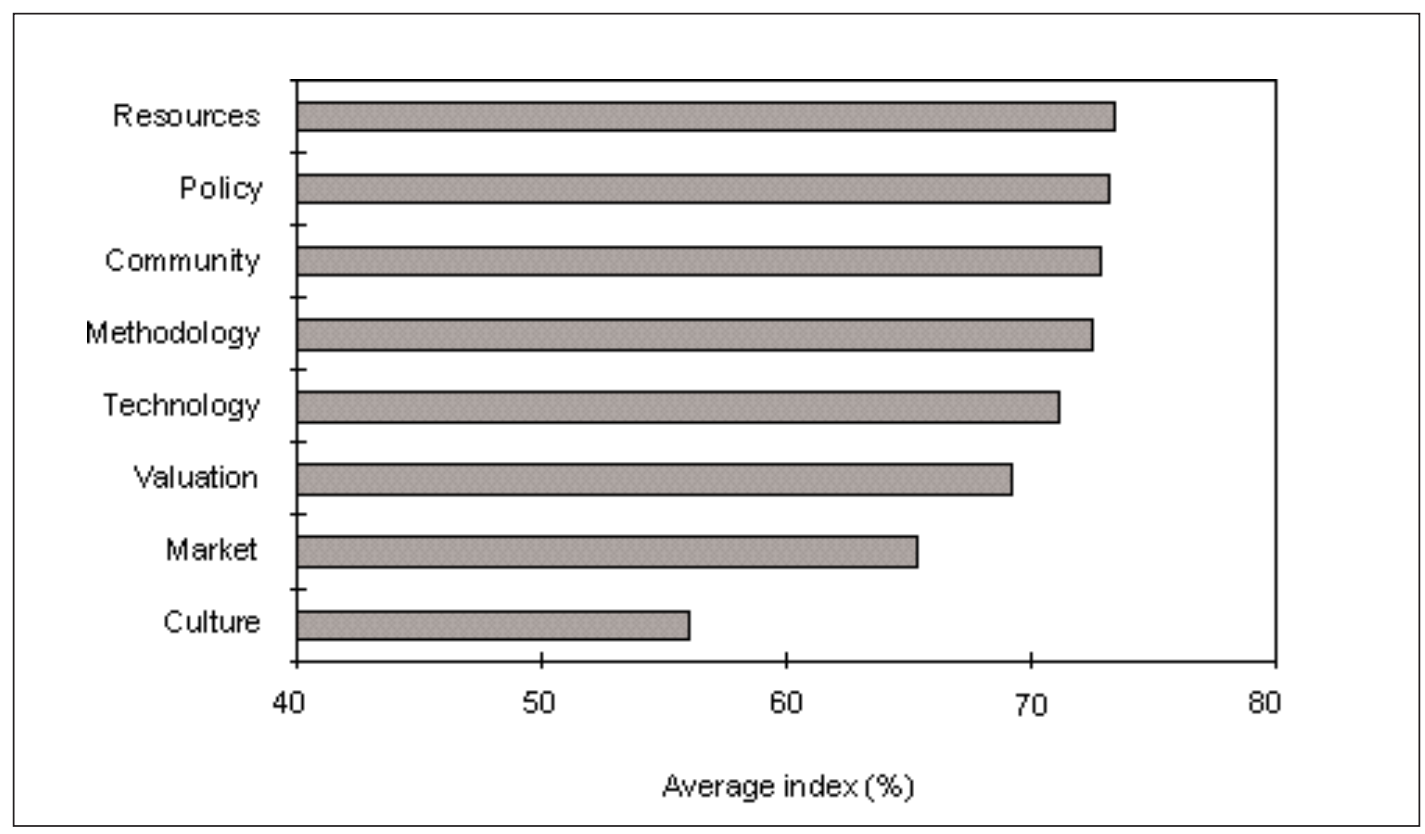

Figure 1. Priority research issues 


\section{Constraints affecting research on non-timber forest products}

The participants were next asked to identify the constraints faced by their organisations in carrying out research. Table 3 presents those constraints identified and the number of participants who named each.

Nineteen constraints were identified, being mentioned a total of 175 times by the nine participants. The number of constraints identified for each theme varies between 7 and 10 with an average of 8.25. Some constraints, such as lack of data, expertise or financial resources, are general constraints that appeared in all the themes, whereas others, such as external influences, lack of legislation or potential mistrust are very theme specific. The number of times identified for each constraint appears in Figure 2. It can be used to assess the perceived relative importance of each.

Three types of constraint based on their relative importance are evident in Figure 2:
- The first type are constraints commonly experienced and affecting all themes. They include:

No. 1. Insufficient personnel with appropriate expertise.

No. 2. Insufficient financial resources.

No. 3. Insufficient data or information available (which in itself is a reflection of the lack of research in the area).

- The next type includes constraints that affect most themes but were identified only by some of the participants. They fall in two distinctive categories:

No. 4. The low priority given by current research policies to non-timber forest product themes and the associated perceived negative bias against research on non-timber forest products as well as lack of fora for articulating research priorities.

Table 3. Constraints for each research theme. The figure indicates the number of participants that mentioned a given constraint

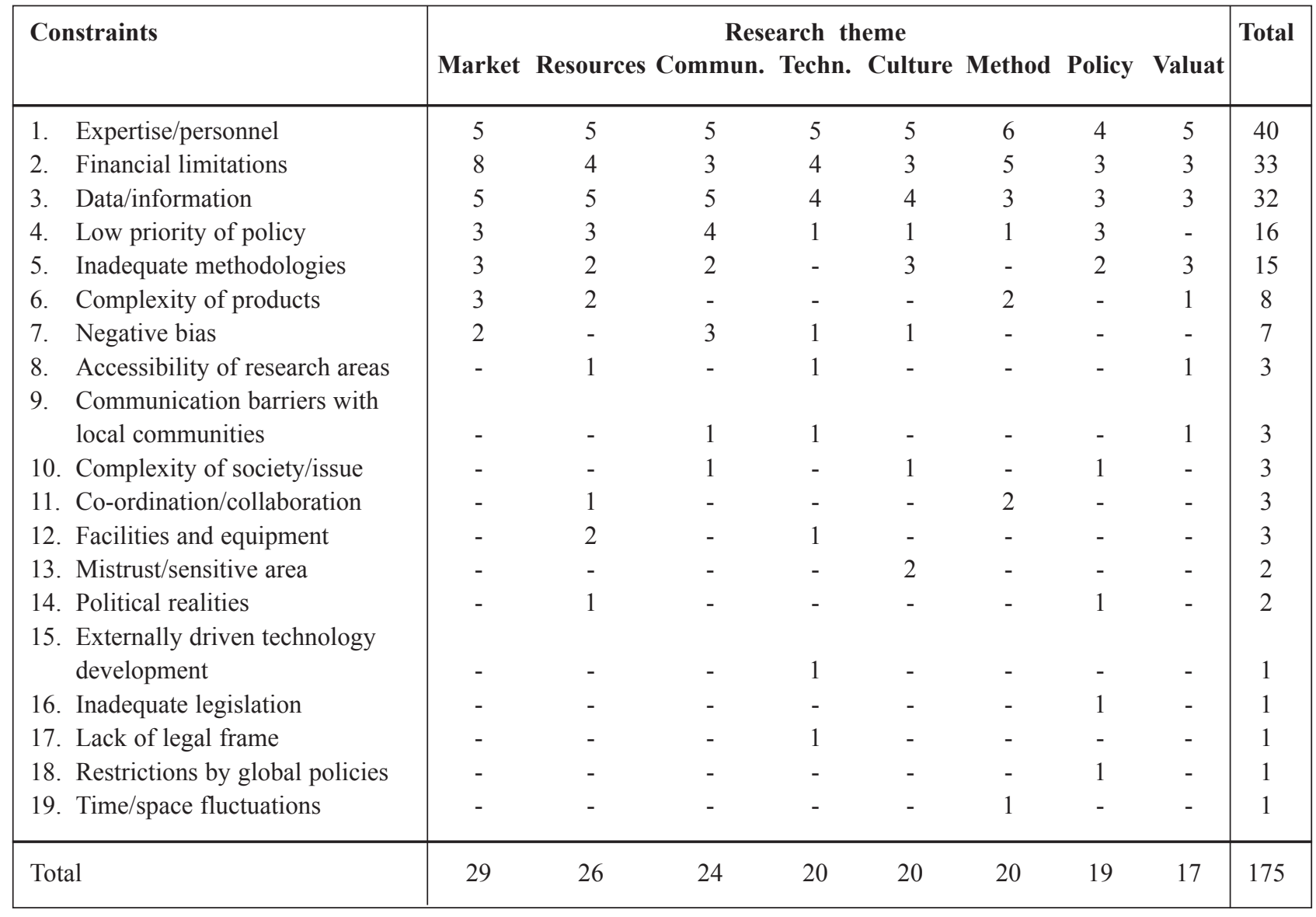


No. 5\&6. The lack of methodologies (which is linked to the poor expertise available) and the complexity of the products.

- Finally, the other constraints (Nos. 7 to 19) are theme specific. These were identified only by a small number of participants.

The total number of times that constraints were mentioned per theme is quite evenly distributed, ranging from 17 to 29 with an average of 21.9.

\section{Proposed solutions to overcome the constraints}

The last part of the workshop was devoted to discussing possible solutions to the constraints identified. No prioritisation of solutions was conducted and during the discussions the solutions were slightly rearranged; they do not follow the same grouping as the constraints. The proposed solutions are presented in Table 4.

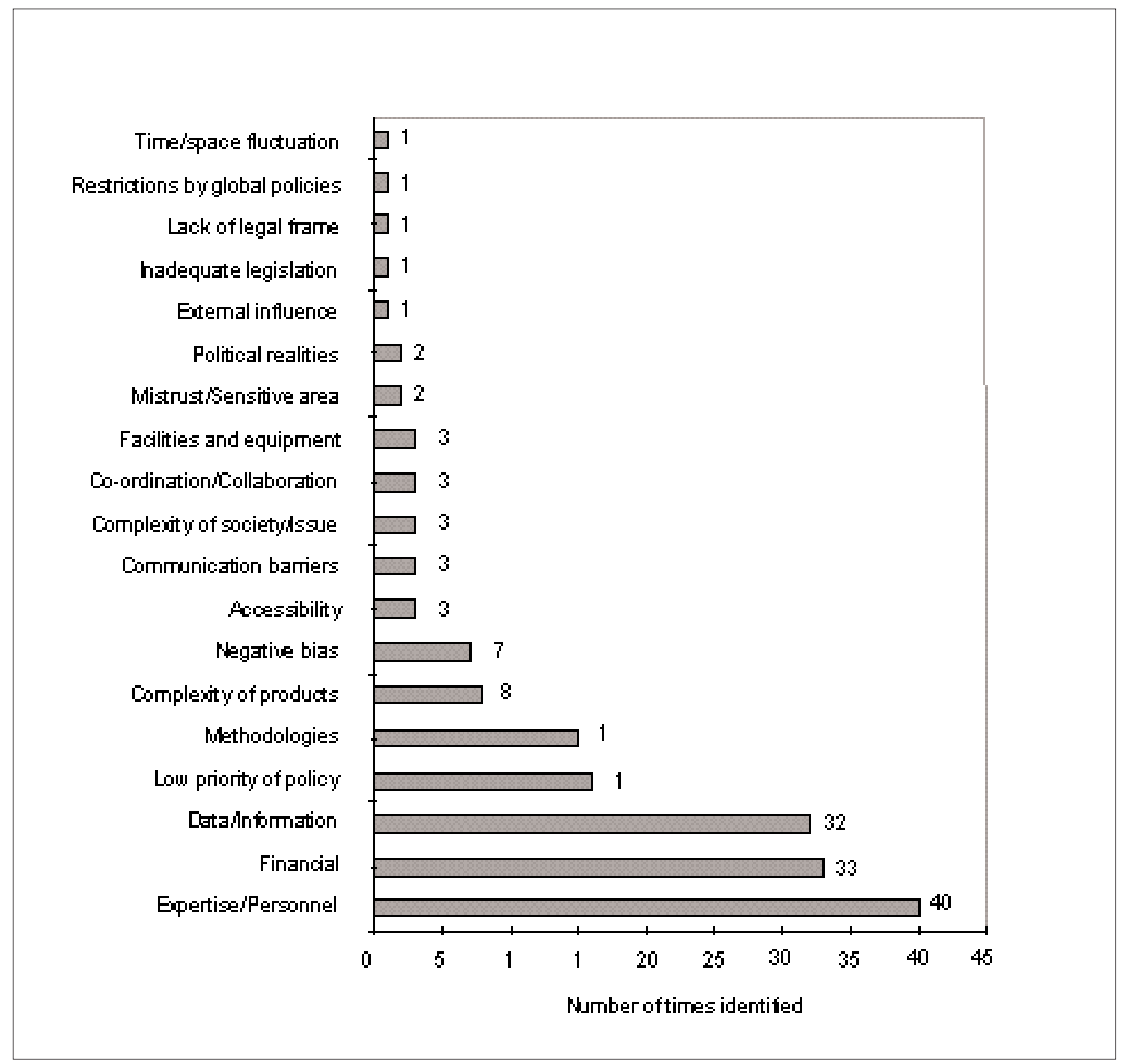

Figure 2. Relative importance of constraints on NTFP research 
Table 4. Proposed solutions to overcome the constraints in research on non-timber forest products

\section{A. Human resources (expertise)}

Training in research on non-timber forest products

Training and employment of local people in research

Consolidation/co-operation/exchange of expertise

Recruitment of more staff

Provision of incentives to scientists for research in hardship areas

Prioritisation of research themes

\section{B. Funding}

Sensitisation of research funding institutions

Commercialisation of research results

Influencing policy on research on non-timber forest products

\section{Facilities and equipment}

Sensitisation of financing institutions

Rationalising and sharing of available facilities

Establishing new/modification of existing facilities

\section{Non-timber forest products - resource base}

Networking

Prioritisation of products for research

Development of common methodologies

Design and implementation of inter-disciplinary research

Synthesis and dissemination of available databases and grey literature

Database integration

\section{E. Organisational constraints (policies, etc.)}

Sensitisation of relevant institutions and organisations, society and policy makers

Building research projects on non-timber forest products into programmes in forestry related fields and institutions

\section{F. Communication}

Packaging and disseminating available research findings

Eliciting greater participation of local communities in issues relating to non-timber forest products Improving co-ordination and rationalising participation in research on non-timber forest products regional and global forums

\section{G. Others}

Exploring patents for traditional knowledge to protect intellectual property rights 


\section{Discussion and Conclusions}

\section{Research themes and issues}

A number of broad themes and directions might be identified as an outcome of the workshop. The priority issues of Table 2 and the priority research themes of Figure 1 can be used to infer the main research gaps as experienced by participants. They relate to:

Natural resources management (issues 2.1 and 6.1)

Policy and institutional arrangements (issues 5.1 and 5.2)

Community roles and social dimensions (issues $6.1,1.1,6.2,3.1$ and 7.2$)$

The importance given to different methodological aspects (issues 7.1 and 7.2) reflects the perceived need for better training and qualified staff.

Only a few issues related to technology and markets (issues 1.1 and 1.2; with a clear component of product development and promotion) were considered urgent, while most of the valuation techniques and cultural aspects do not appear to be of high priority.

Many of the priorities identified overlap to some extent with the issues identified in CIFOR's framework for research on non-timber forest products (Ruiz Pérez 1995).

\section{Constraints and solutions}

Participants agreed that most of the constraints are internally determined and that they are similar to problems faced by other research activities in the region. However, a number of constraints are related to external factors, which is especially relevant for action research and development-oriented research. Examples of this include constraint no. 15, externally driven technological development, and constraint no. 18 , restrictions imposed by global policies.

The proposed actions to overcome the constraints also include options common to many other types of research (Table 4: A. Human resources; B. Funding; C. Facilities and equipment; E. Organisational constraints; and elements of F. Communication). Some other suggested solutions address the distinct nature of nontimber forest products as research subjects (Table 4, D. Non-timber forest products - resource base (diversity, inter-disciplinary); G. Others (patenting); and elements of F. Communication (participation)).

\section{The workshop process}

Before drawing any firm conclusions on the information generated at the workshop, a word of caution is appropriate in relation to the role of the meeting as a research programming tool. It should be emphasised that, although the participants included most senior staff of respected forest research institutions in the region, their small number and relatively homogeneous professional background would certainly introduce bias into the outcomes of the meeting, just as would any other composition of the group. The fact that most were foresters with extensive research management and policy design responsibilities could be reflected in the results. Therefore, the workshop should be considered as a first, though authoritative, approximation to the needs in research on non-timber forest products in Southern and East Africa, based on the analysis by nine experts - nothing more and nothing less.

In fact, an important basic conclusion of the workshop might be that not only the research topic under review (non-timber forest products) is different from the traditional forest research subject (timber) but that, in order to address the subject in a meaningful way, the mechanisms to define research questions and research methods should be adjusted as well. The main significance of non-timber forest products is at the local and subsistence level and therefore research questions and methods should be defined at that level in an iterative process of action research, involving researchers and local users and managers of the forest (Gilmour et al. 1987). Many, if not all, of the broad themes and issues identified during the meeting can be elaborated and refined into workable research questions through such iterative processes. The development of participatory research methods, necessary for this approach, was identified as one of the ten priority issues by the participants (issue 7.2).

\section{Follow-up actions}

The purpose of the meeting was to identify research priorities and to promote collaboration between the participating institutions. A brief review of some examples from the region of research initiatives related to nontimber forest products (Annex I) indicates that many of the themes and issues identified during the workshop are being addressed in at least one research project. Yet, the participants agreed that non-timber forest products do not yet form part of mainstream forest research programmes. On-going research and development programmes on or embracing non-timber forest products remain scarce, dispersed in different institutions and largely driven by personal interests of individual scientists.

Traditionally, forest research is being carried out by universities, forest research institutes and, for ethno-botanical studies, by national museums. More and more, this research is being complemented by activities from other "non traditional" research institutions, such as non-governmental organisations (NGOs), often as a component of forest management and conservation projects or integrated conservation and development projects (ICDPs). 
Reflecting the action research approach described above, these initiatives attempt to address issues through a process in which management questions, research activities and pilot implementation go hand in hand, and whereby the link between researchers and stakeholders is (or should be) very close.

Often, but not always, the link between these action-oriented research initiatives and the traditional research programmes is absent or weak. An important step in enhancing the capacity to address research issues about non-timber forest products would be to strengthen the linkages between these various initiatives and activities, for example, through sharing information and experiences.

It was not the purpose of this meeting to design specific projects and programmes, but it was felt by the participants that an elaboration of the findings of the meeting into specific action would be the only useful next step. It was agreed that the Kenya Forest Research Institute (KEFRI) would take the lead in this, together with IUCN's Eastern Africa Regional Office.

\section{Acknowledgements}

The authors thank Dr. Godwin Kowero and Dr. Neil Byron for their comments. They also thank Janet Awimbo and Yemi Tessema for their assistance in the editing of the background documents presented during the workshop, and Yvonne Byron for the editing of the present document. 


\section{References}

Allegretti, M.H. 1989. Reservas Extrativistas. Una proposta de desenvolvimento para a Floresta Amazônica. São Paulo em Perspectiva 3(4): 23-29.

Aluma, J.R.W. 1995. Non-timber forest products management in Uganda. Background paper prepared for the workshop "Research priorities on NTFP in East and Southern Africa", Nairobi, September 1995.

Anderson, A.B. 1990. Alternatives to Deforestation: Steps toward Sustainable Use of the Amazon Rain Forest. Columbia University Press, New York.

Bennett, B.C. 1992. Plants and people of the Amazonian rainforest. The role of ethnobotany in sustainable development. BioScience 42: 599-607.

Bodmer, R.E., T.G. Fang and I.L. Moya. 1988. Primates and ungulates: a comparison in susceptibility to hunting. Primate Conservation 9: 79-83.

Browder, J.O. 1992. The limits of extractivism. Tropical forest strategies beyond extractive reserves. BioScience 42: $174-182$.

Campbell, B. (ed.). 1996. The Miombo in Transition: Woodlands and Welfare in Africa. Center for International Forestry Research (CIFOR), Bogor, Indonesia.

CATIE. 1992. Informe Final del Proyect 'Conservación para el Desarrollo Sostenible' Fase I. Unpublished report. CATIE. Turrialba, Costa Rica.

Clay, J. and C.R. Clement. 1993. Selected Species and Strategies to Enhance Income Generation from Amazonian Forests. FAO Working Paper. FAO, Rome.

Conklin, B.A. and L.R. Graham. 1995. The shifting middle ground: Amazonian Indians and eco-politics. American Anthropologist 97: 695-710.

Crafter, S.A., J. Awimbo and J.A. Broekhoven. 1996. Non-timber Forest Products: Value, Use and Management Issues in Africa, including Examples from Latin America. Proceedings of a workshop held in Naro Moro, Kenya, 8-13 May 1994. IUCN, Gland.

Cunningham, A. B. 1993. African Medicinal Plants. Setting Priorities at the Interface between Conservation and Primary Health Care. People and Plants Working Paper No. 1. UNESCO, Paris.

de Beer, J.H. and M.J. McDermott. 1989. The Economic Value of Non-timber Forest Products in South East Asia. The Netherlands Committee for IUCN, Amsterdam.

Dewees, P.A. 1989. The woodfuel crisis reconsidered: observations on the dynamics of abundance and scarcity. World Development 17: 1159-1172.

Falconer, J. 1990. The Major Significance of "Minor" Forest Products. The Local Use and Value of Forests in the West African Humid Forest Zone. Community Forestry Note, 6. FAO, Rome.

Falconer, J. and J.E.M. Arnold. 1989. Household Food Security and Forestry. An Analysis of Socio-economic Issues. Community Forestry Note, 1. FAO, Rome.

FAO. 1995a. Report on the Expert Consultation on Non-Wood Forest Products, Yogyakarta, Indonesia, 17-27 January 1995. Non-Wood Forest Products 3. FAO, Rome.

FAO. 1995b. Forest Resources Assessment 1990. Forestry Paper 124. FAO, Rome.

Fearnside, P. 1989. Extractive reserves in Brazilian Amazonia. An opportunity to maintain tropical rain forest under sustainable use. BioScience 39: 387-393.

French, D. 1986. Confronting an unsolvable problem: deforestation in Malawi. World Development 14: 531-540.

Gilmour, D.A., C.C. King and R.J. Fisher. 1987. Action research into socio-economic aspects of forest management. In IUFRO, Role of Forest Research in Solving Socio-economic Problems in the Himalaya Region, pp. 41-48. IUFRO Symposium, Forest Research Institute, Peshawar, Pakistan. 
González, N. 1992. We are not conservationists. Cultural Survival Quarterly 16(3): 43-45.

Kenya Forestry Master Plan. 1994. Development Programmes. Ministry of Environment and Natural Resources, Nairobi.

Kowero, G.S. 1990. Management of forest estates in Tanzania: some policy issues. Journal of World Forest Resource Management 5: 15-27.

Lescure, J.P. (coordinateur).1995. Extractivisme en Amazonic. Viabilite et Développement. ORSTOM-INPAAarhus University, Paris.

Lowore, J.D. 1995. Research on non-timber forest products and community forestry in Malawi. Background paper prepared for the workshop "Research priorities on NTFP in East and Southern Africa", Nairobi, September 1995.

Ministry of Natural Resources of Uganda. 1994. State of the Environment Report for Uganda 1994. Ministry of Natural Resources, Kampala.

Mutemwa, S.M. 1995. Report on research priorities on non-timber forest products and community forestry in Zambia. Background paper prepared for the workshop "Research priorities on NTFP in East and Southern Africa", Nairobi, September 1995.

Myers, N. 1986. Forestland farming in Western Amazonia: stable and sustainable. Forest Ecology and Management 15: 81-93.

Nepstad, D.C. and S. Schwartzman (eds). 1992. Non-timber Products from Tropical Forests. Evaluation of a Conservation and Development Strategy. Advances in Economic Botany 9: whole volume.

Odera, J.A. 1995. Report on research priorities on non-timber forest products and community forestry in Kenya. Background paper prepared for the workshop "Research priorities on NTFP in East and Southern Africa", Nairobi, September 1995.

Panayotou, T. and P. Ashton. 1992. Not by Timber Alone. Economics and Ecology for Sustaining Tropical Forests. Island Press, Washington, DC.

Peters, C.M. 1996. The Ecology and Management of Non-timber Forest Products. World Bank Technical Paper No. 322. World Bank, Washington, DC.

Peters, C.M., A.H. Gentry and R.O. Mendelsohn. 1989. Valuation of an Amazonian rain forest. Nature 339: 655-656.

Plotkin, M.J. and L.M. Famolare (eds). 1992. Sustainable Harvests and Marketing of Rain Forest Products. Conservation International-Island Press, Washington, DC.

Redford, K.H. 1992. The empty forest. BioScience 42: 412-422.

Redford, K.H. and C. Padoch. 1992. Conservation of Neotropical Forests. Working from Traditional Resource Use. Columbia University Press, New York.

Redford, K.H. and A.M. Stearman. 1993. Forest-dwelling native Amazonians and the conservation of biodiversity: interests in common or in collision? Conservation Biology 7: 248-255.

Ros-Tonen, M., W. Dijkman and E. L. van Bueren. 1995. Commercial and Sustainable Extraction of Non-timber Forest Products. Towards a Policy and Management Oriented Research Strategy. The Tropenbos Foundation, Wageningen, The Netherlands.

Ruiz Pérez, M. 1995. A Conceptual Framework for CIFOR's Research on Non-wood Forest Products. CIFOR Working Paper No. 6. CIFOR, Bogor, Indonesia.

Ruiz Pérez, M. and J.E.M. Arnold (eds). 1996. Current Issues in Non-Timber Forest Products Research. Proceedings of the Workshop 'Research on NTFP'. Hot Springs, Zimbabwe, 28 August - 2 September 1995. CIFOR and ODA, Bogor, Indonesia.

Townson, I.M. 1995. Forest Products and Household Incomes. A Review and Annotated Bibliography. OFICIFOR, Oxford. 


\begin{tabular}{|c|c|c|c|c|c|c|c|}
\hline \multirow{6}{*}{ 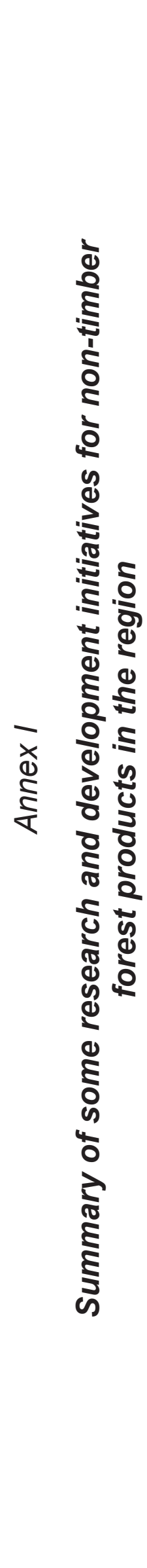 } & & 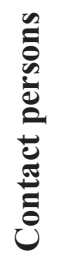 & 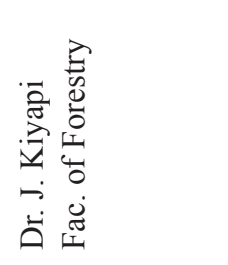 & 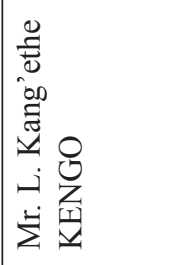 & 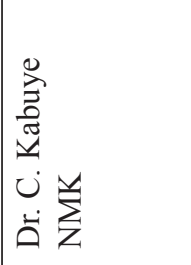 & 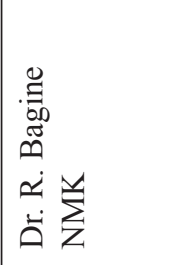 & 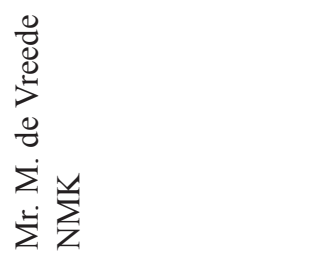 \\
\hline & & 氖 & $\begin{array}{l}\frac{1}{\sigma} \\
\frac{9}{2} \\
\frac{9}{2}\end{array}$ & 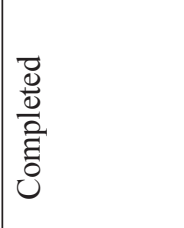 & $\begin{array}{l}\infty \\
2 \\
\sigma \\
2 \\
\vdots \\
2 \\
2\end{array}$ & 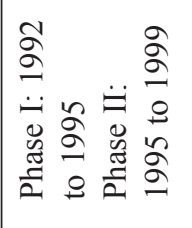 & $\begin{array}{l}\infty \\
\stackrel{\infty}{\sigma} \\
\stackrel{2}{+} \\
\stackrel{2}{\sigma}\end{array}$ \\
\hline & & 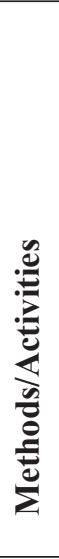 & 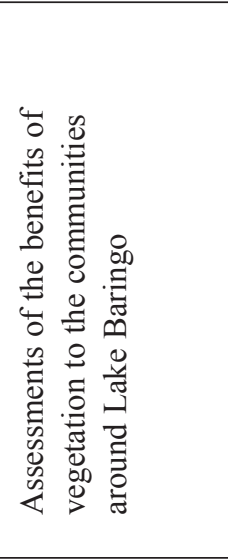 & 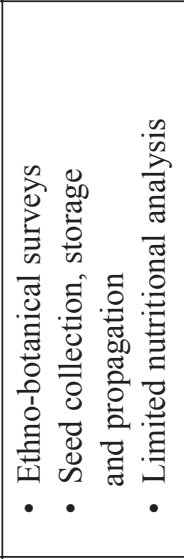 & 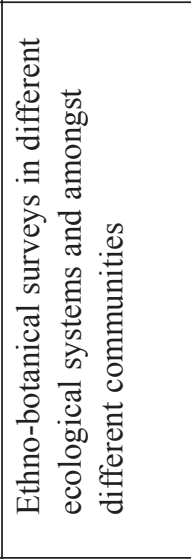 & 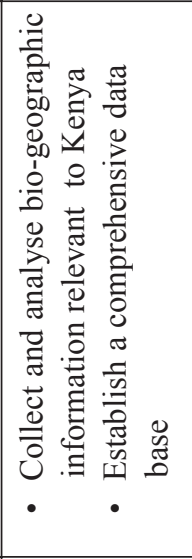 & 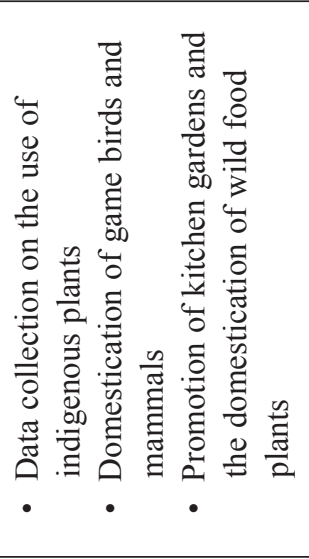 \\
\hline & & 窇 & 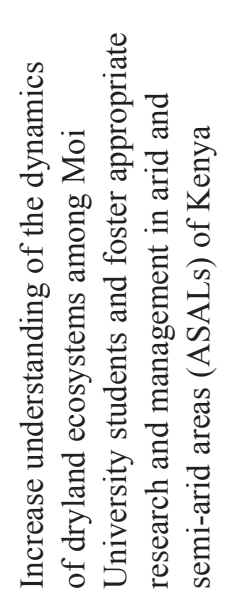 & ' & 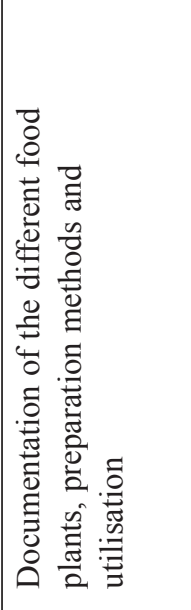 & 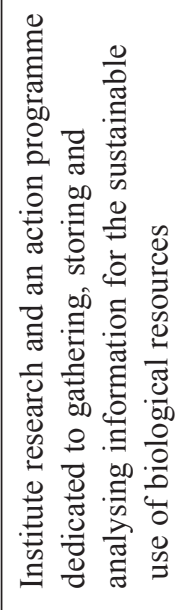 & 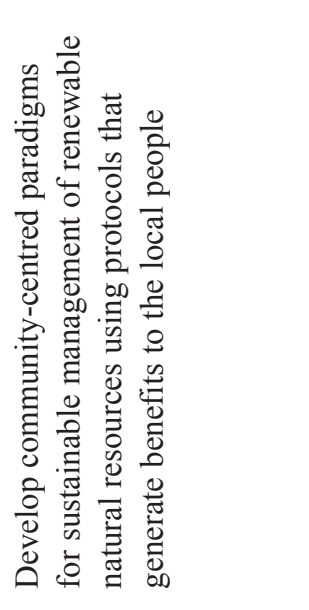 \\
\hline & $\begin{array}{l}\frac{\pi}{0} \\
\frac{0}{0} \\
0 \\
\dot{4} \\
i\end{array}$ & 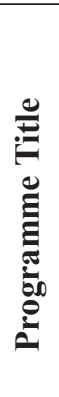 & & 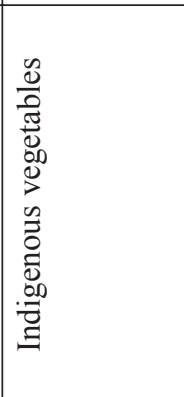 & 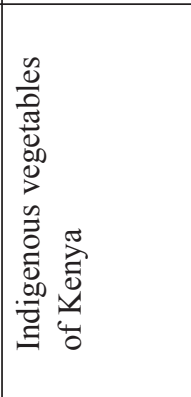 & 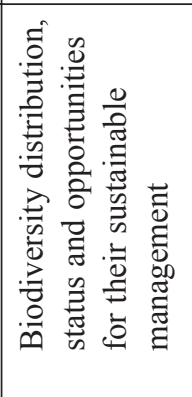 & 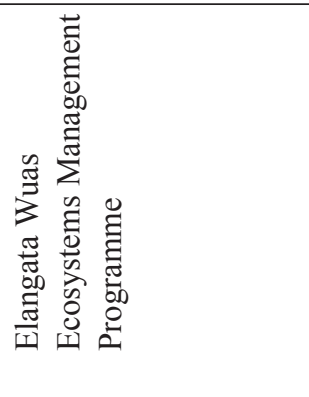 \\
\hline & 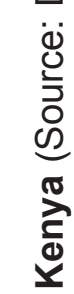 & & 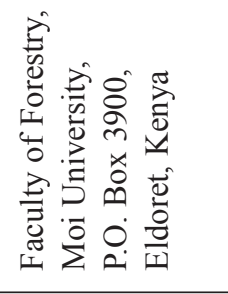 & 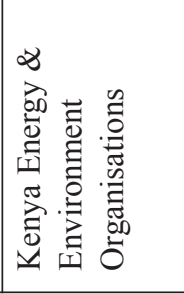 & 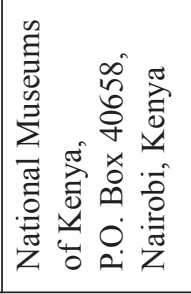 & 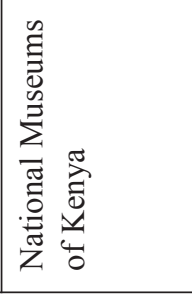 & 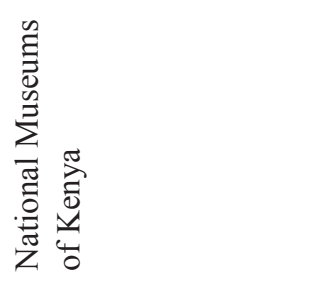 \\
\hline
\end{tabular}




\begin{tabular}{|c|c|c|c|c|}
\hline 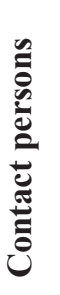 & 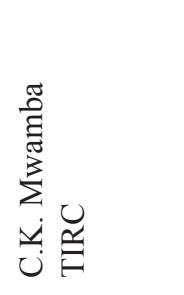 & 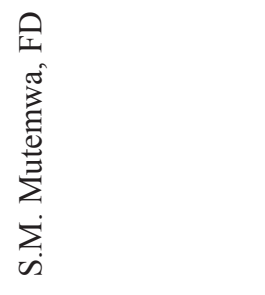 & 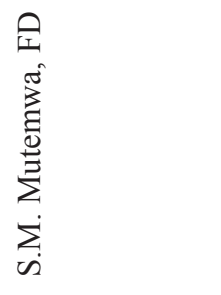 & 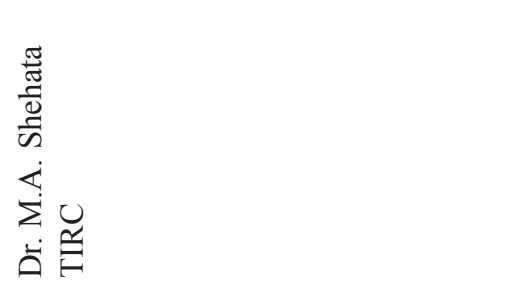 \\
\hline (气) & ' & ' & 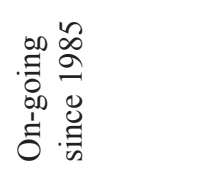 & 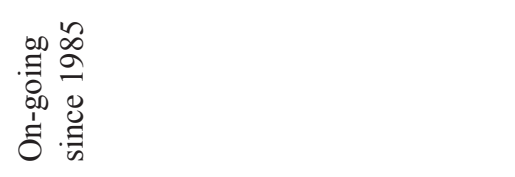 \\
\hline 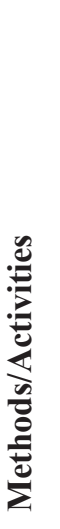 & 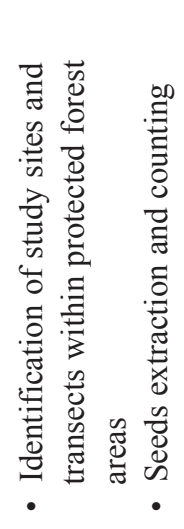 & 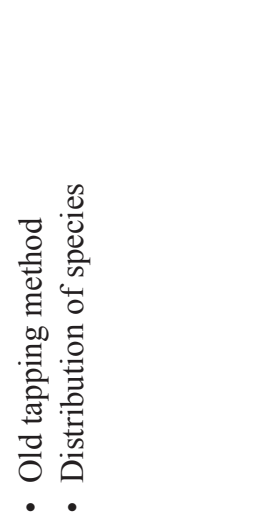 & 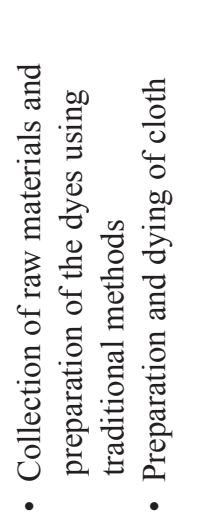 & 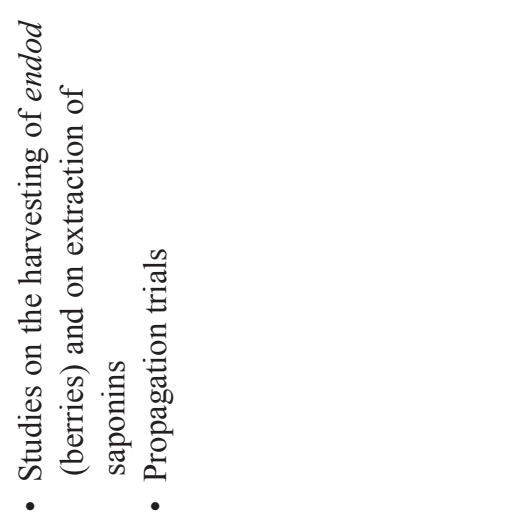 \\
\hline$\frac{\sum_{0}^{0}}{e_{0}^{0}}$ & 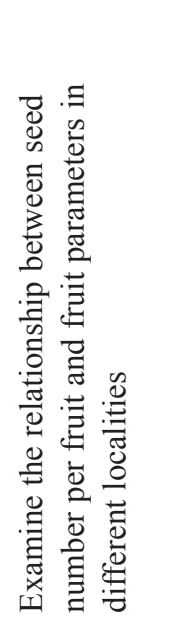 & 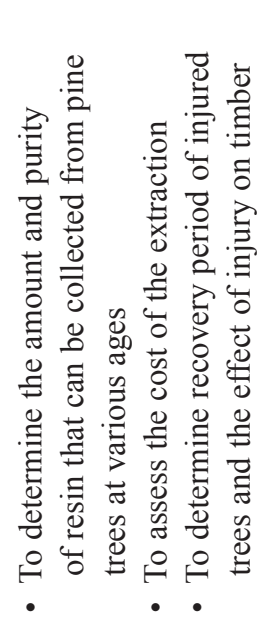 & 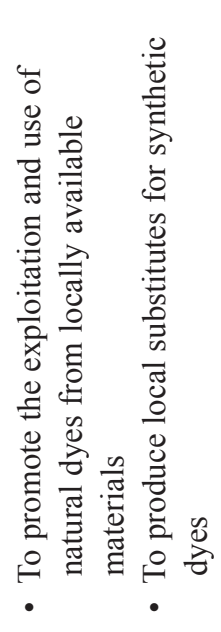 & 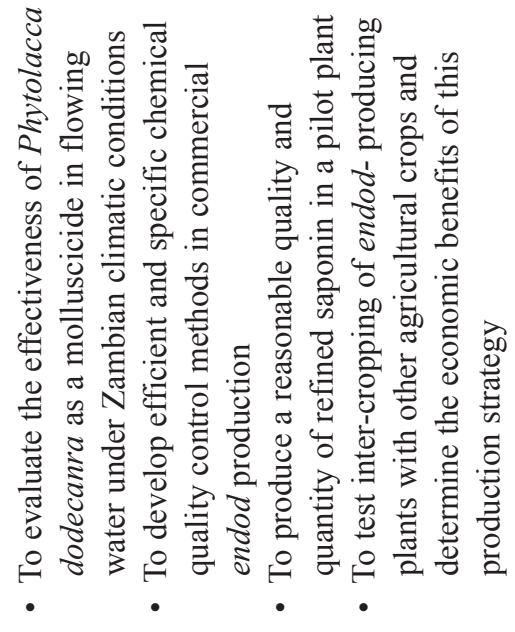 \\
\hline : & 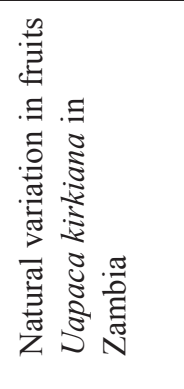 & 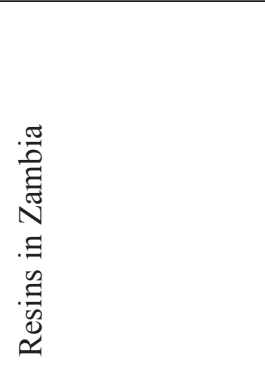 & 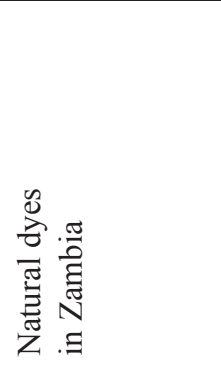 & 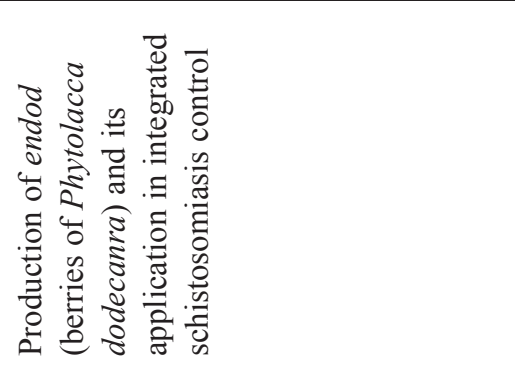 \\
\hline 号 & 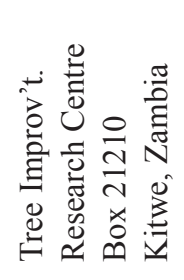 & 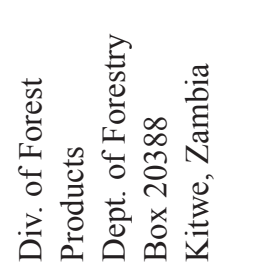 & 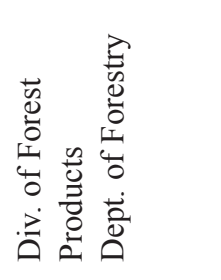 & 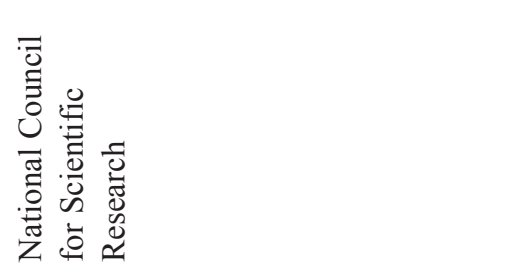 \\
\hline
\end{tabular}




\begin{tabular}{|c|c|c|c|c|}
\hline 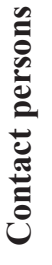 & 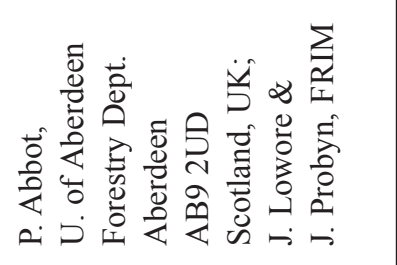 & 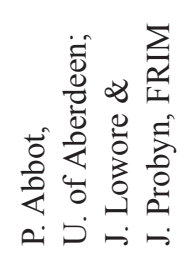 & 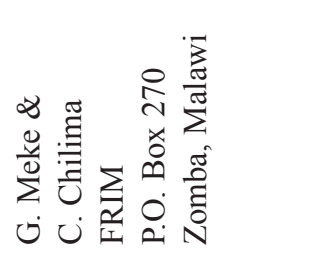 & 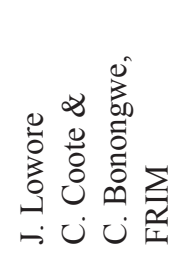 \\
\hline (气) & & $\begin{array}{l}\stackrel{n}{\sigma} \\
\frac{a}{a} \\
\sigma\end{array}$ & $\begin{array}{l}\text { बे } \\
\frac{1}{2} \\
\text { ळे }\end{array}$ & $\begin{array}{l}\text { ลे } \\
\frac{1}{0} \\
\text { aे }\end{array}$ \\
\hline 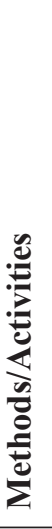 & 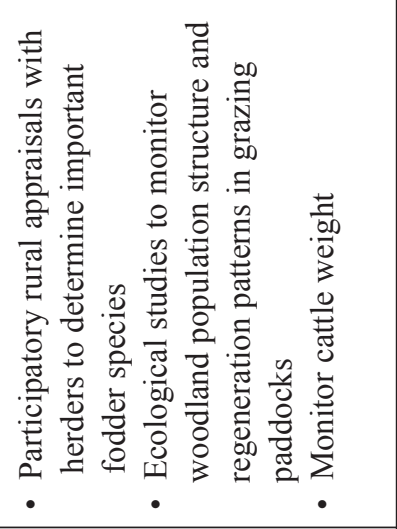 & 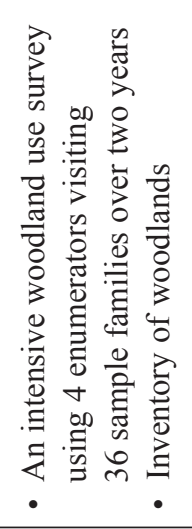 & 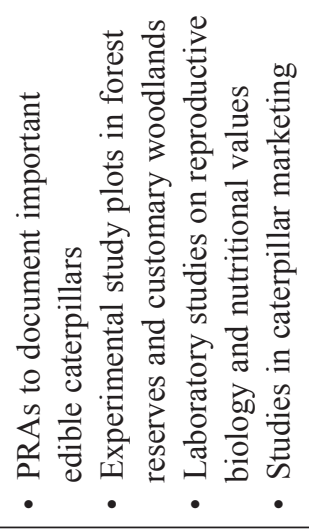 & 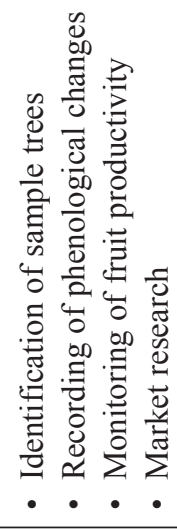 \\
\hline 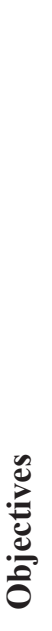 & 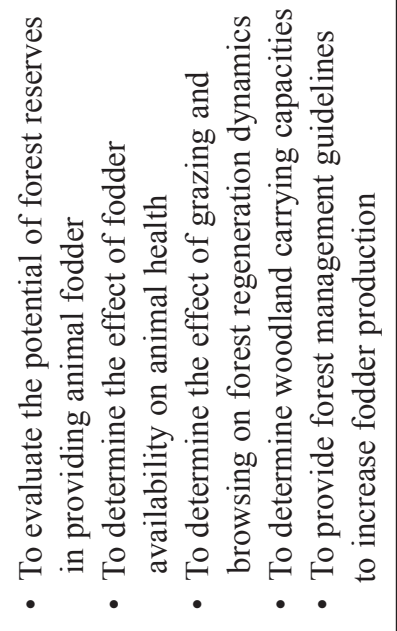 & 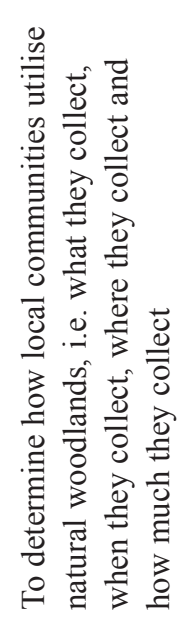 & 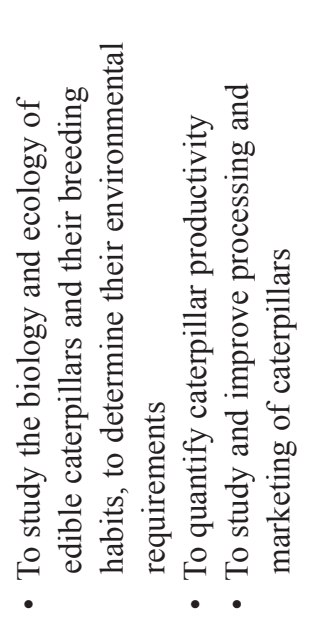 & 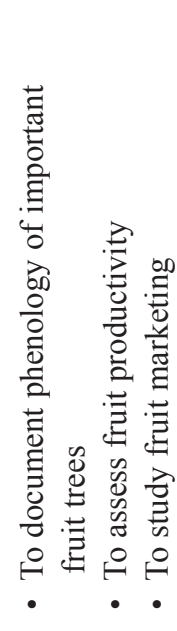 \\
\hline 总 & 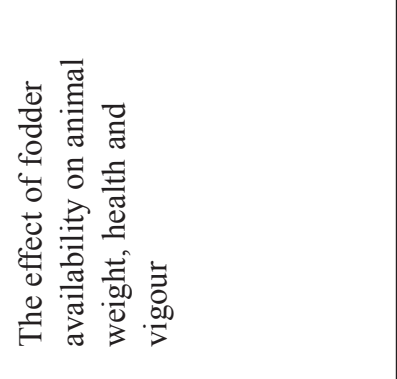 & 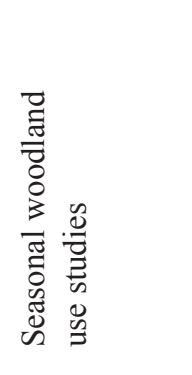 & 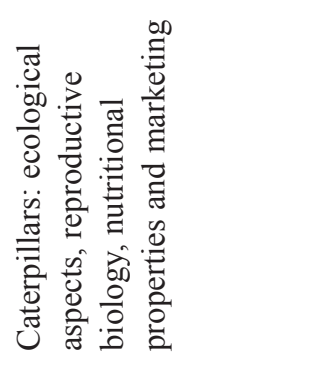 & 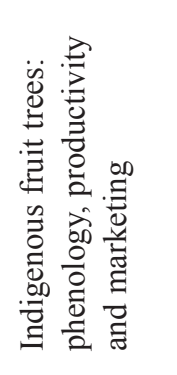 \\
\hline 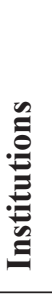 & 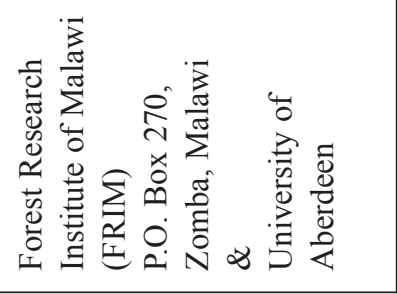 & 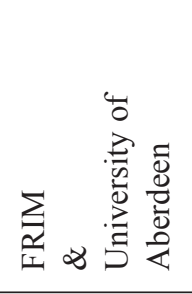 & 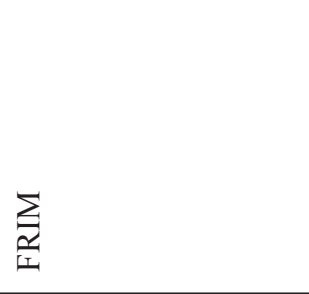 & 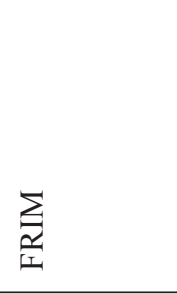 \\
\hline
\end{tabular}




\begin{tabular}{|c|c|c|c|c|c|}
\hline 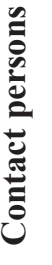 & 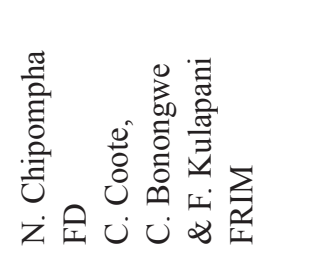 & 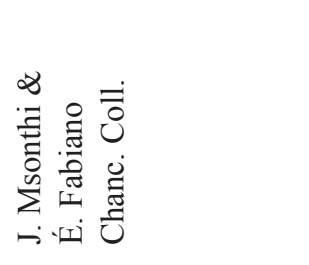 & 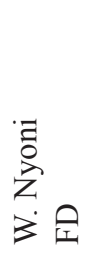 & 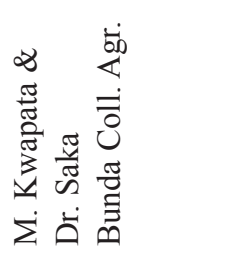 & 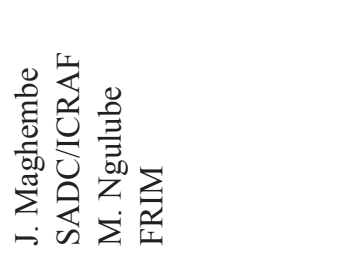 \\
\hline مَ & $\begin{array}{l}\text { बे } \\
\frac{\hat{\sigma}}{\sigma}\end{array}$ & 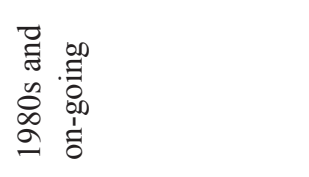 & 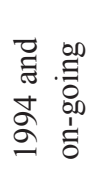 & 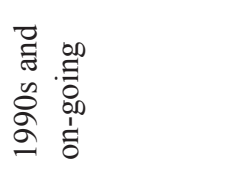 & 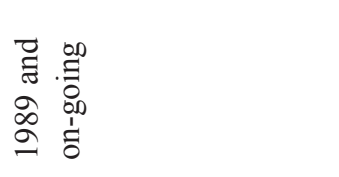 \\
\hline 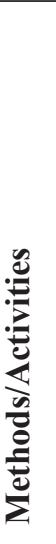 & 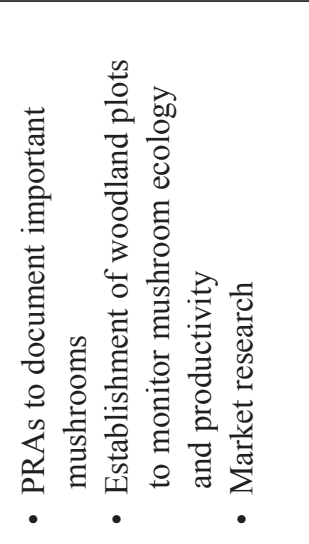 & 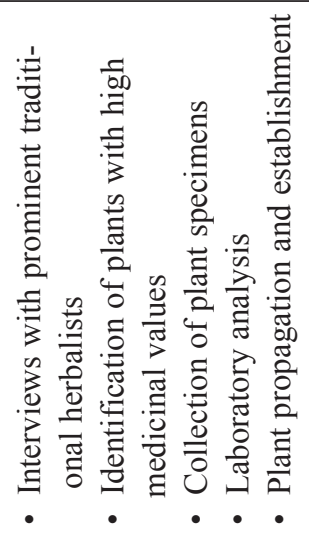 & 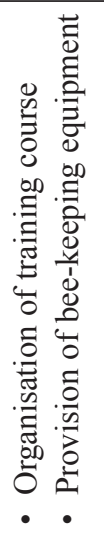 & 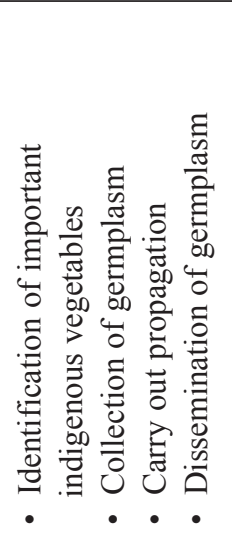 & 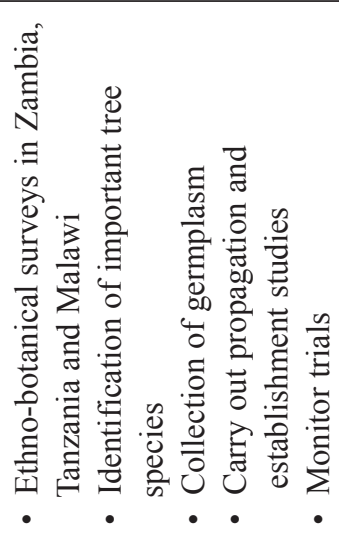 \\
\hline & 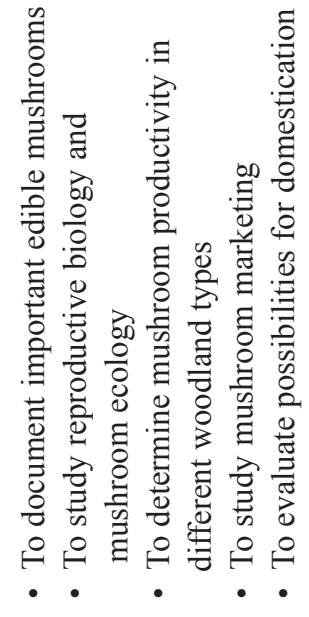 & 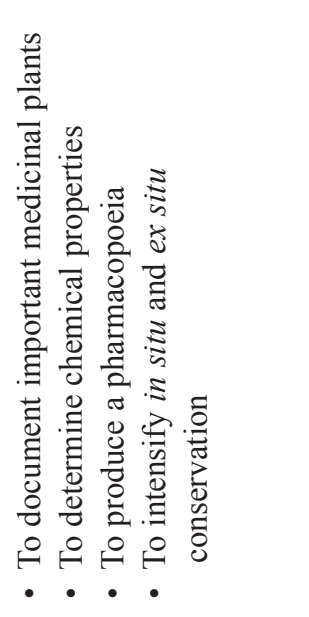 & 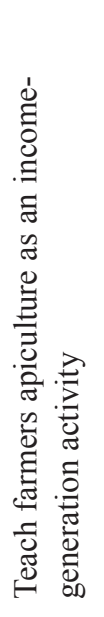 & 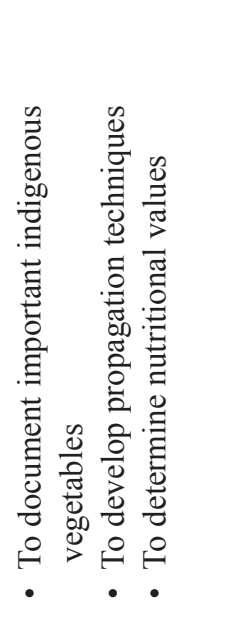 & 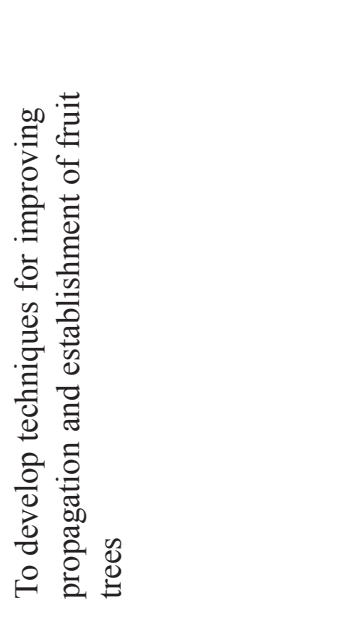 \\
\hline 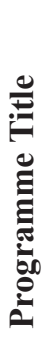 & 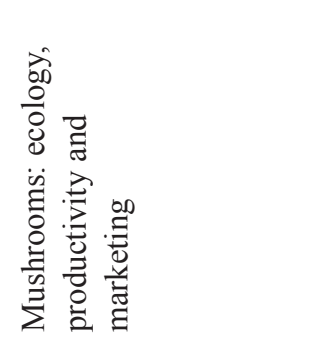 & 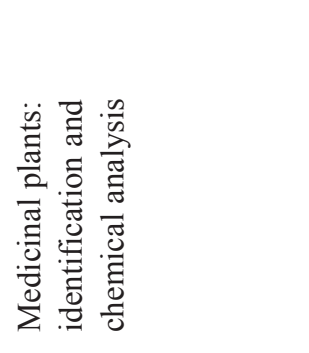 & 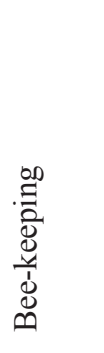 & $\begin{array}{l}0 \\
\frac{0}{10} \\
\overline{0} \\
0 \\
0 \\
0 \\
0 \\
0 \\
0 \\
0 \\
.00 \\
.00 \\
\Xi\end{array}$ & 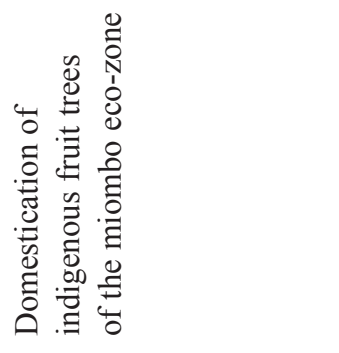 \\
\hline .气.气. & 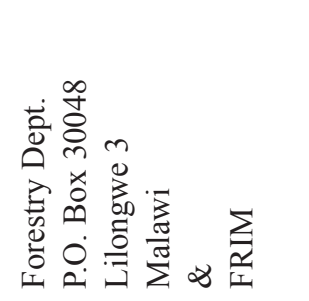 & 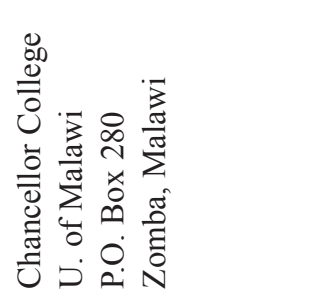 & 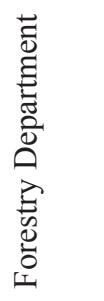 & 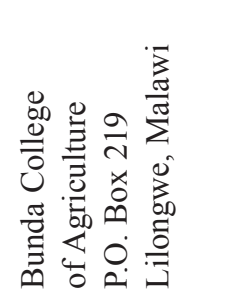 & 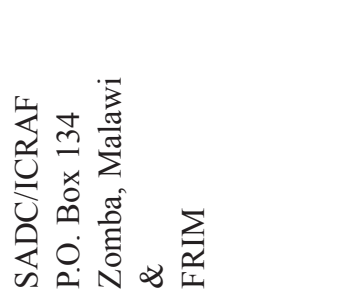 \\
\hline
\end{tabular}




\begin{tabular}{|c|c|c|c|}
\hline 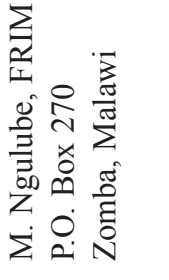 & 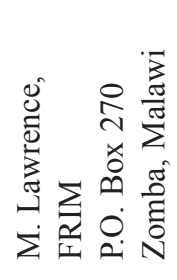 & 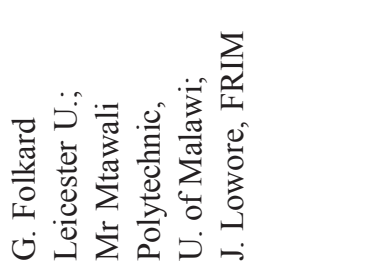 & 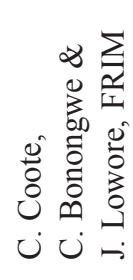 \\
\hline & $\begin{array}{l}\stackrel{0}{2} \\
\frac{\partial}{+} \\
\text { よे }\end{array}$ & 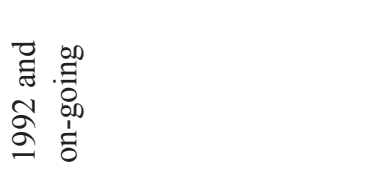 & 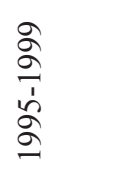 \\
\hline 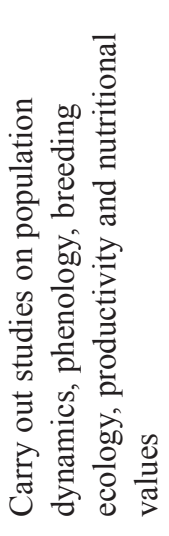 & 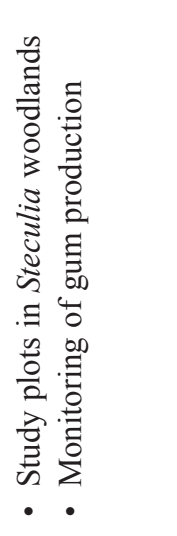 & 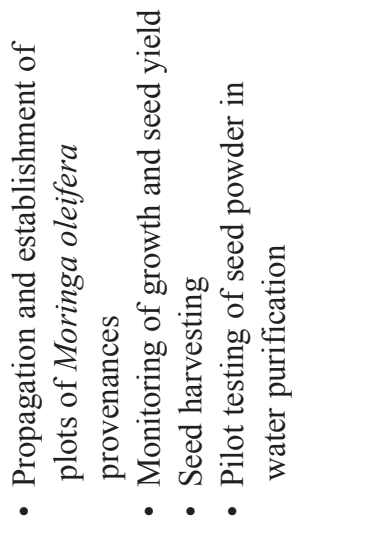 & 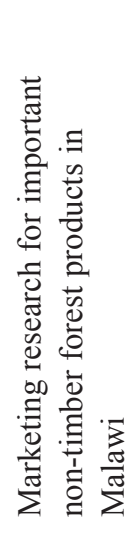 \\
\hline 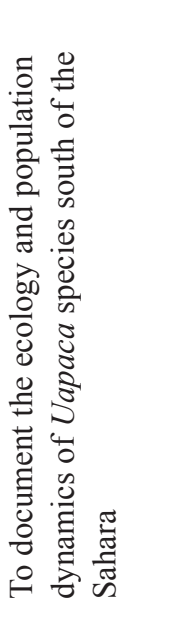 & 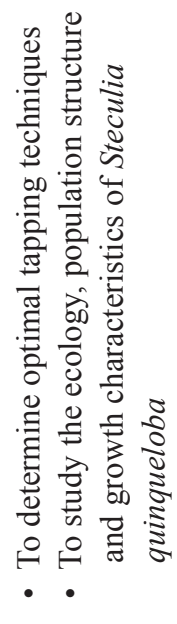 & 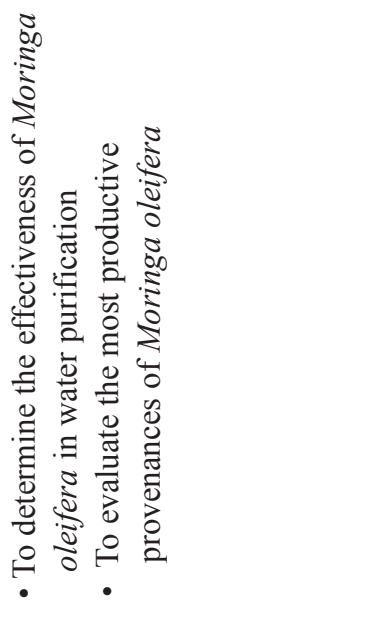 & 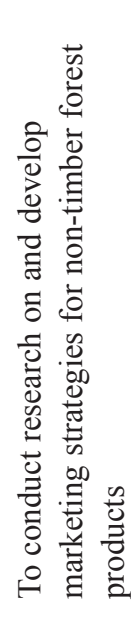 \\
\hline 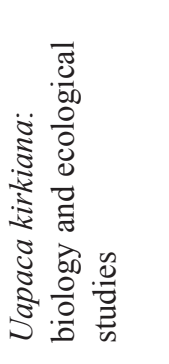 & 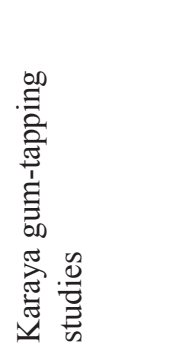 & 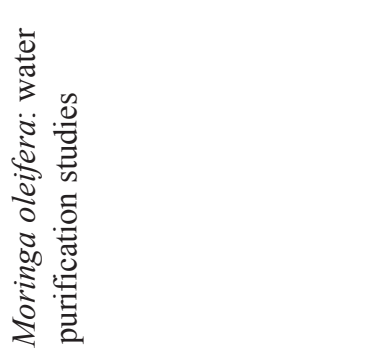 & 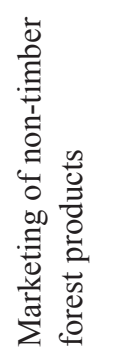 \\
\hline$\frac{\text { d }}{\underline{x}}$ & 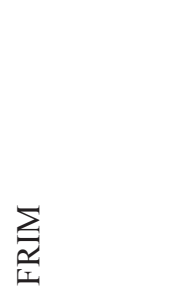 & 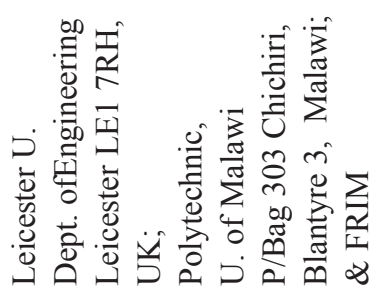 & $\sum_{\substack{||}}$ \\
\hline
\end{tabular}



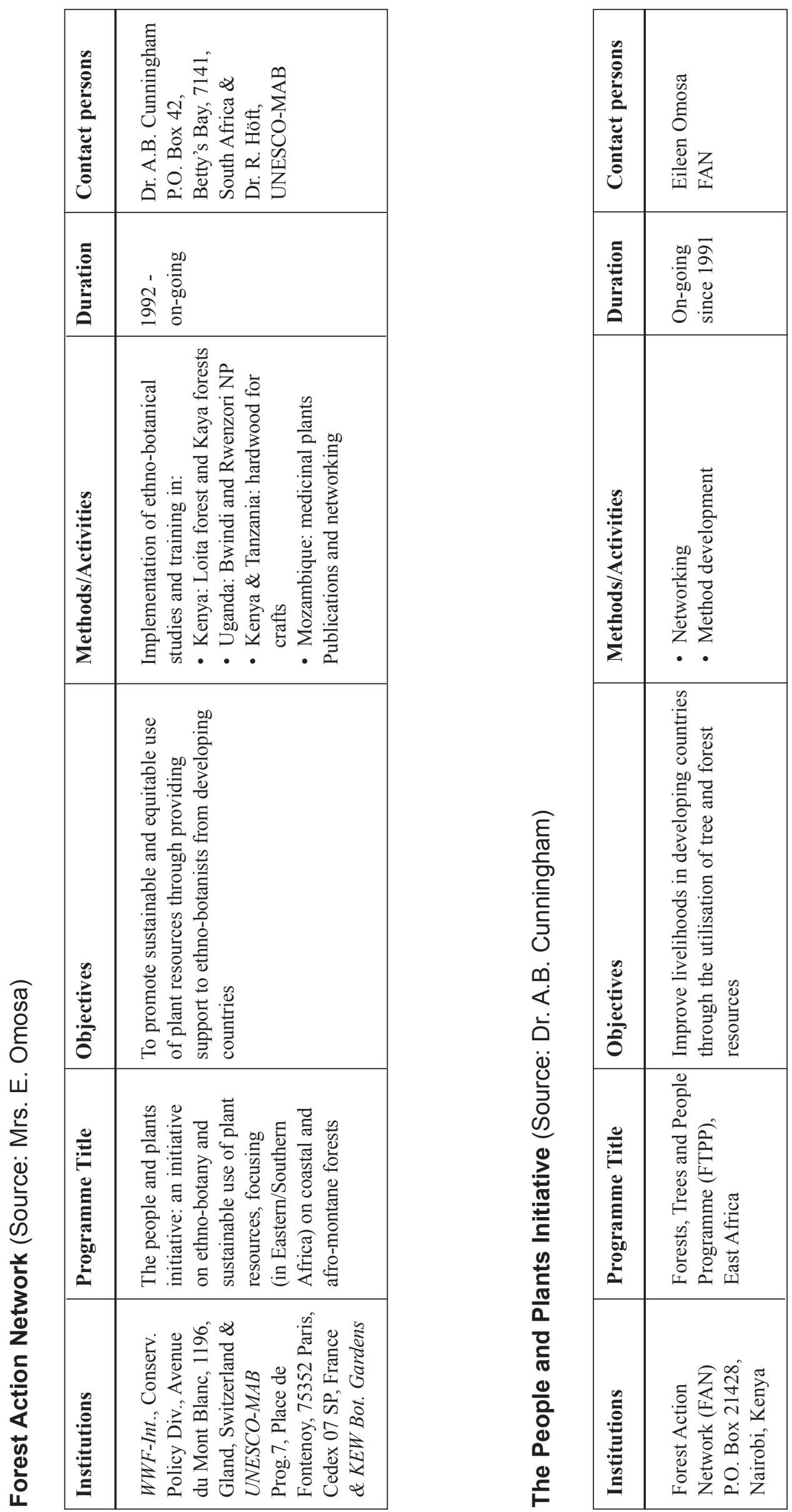
Annex II

Area of forest and other wooded land 1990 ('000 ha)

\begin{tabular}{|l|c|c|c|c|c|c|c|}
\hline Country & \multirow{2}{*}{ Land Area } & \multirow{2}{*}{$\begin{array}{l}\text { Forest and Other } \\
\text { Wooded land }\end{array}$} & \multicolumn{4}{|c|}{$\begin{array}{c}\text { Forest } \\
\text { Other } \\
\text { Wooded Land }\end{array}$} \\
\cline { 4 - 8 } & & & Total & $\begin{array}{c}\text { \% of } \\
\text { land area }\end{array}$ & Natural & Plantation & \\
\hline Kenya & 56969 & 16816 & 1305 & 2 & 1187 & 118 & 15511 \\
\hline Uganda & 19955 & 16023 & 6366 & 32 & 6346 & 20 & 9657 \\
\hline Tanzania & 88604 & 68497 & 33709 & 38 & 33555 & 154 & 34788 \\
\hline Malawi & 9408 & 3724 & 3612 & 38 & 3486 & 126 & 112 \\
\hline Zambia & 74339 & 60337 & 32349 & 44 & 32301 & 48 & 27988 \\
\hline
\end{tabular}

Source: FAO 1995b. 


\section{Annex III \\ List of workshop participants (positions held at the time of the workshop)}

Dr. J.R.W. Aluma

Director, Forestry Research Institute

Kampala - Uganda

Ms. Janet Achieng Awimbo

Tutorial Fellow, Department of Zoology, University of Nairobi

Nairobi - Kenya

Mr. Guido Broekhoven

Forest Programme Coordinator, IUCN - Eastern Africa Regional Office

Nairobi - Kenya

Ms. Lucy Emerton

Resource Economist, African Wildlife Foundation (AWF)

Nairobi - Kenya

Prof. S. Iddi

Director, Forest and Beekeeping Division, Ministry of Tourism, Natural Resources and Environment

Dar-es-Salaam - Tanzania

Dr. P.K.A. Konuche

Director, Kenya Forestry Research Institute (KEFRI)

Nairobi - Kenya

Dr. Godwin Kowero

CIFOR

Bogor - Indonesia

Dr. Jimmy D. Lowore

Forest Research Officer, Indigenous Forest Department, Forestry Research Institute of Malawi (FRIM)

Zomba - Malawi

Mr. Martin Mutemwa

Chief Forest Products Research Officer, Forest Products Department

Kitwe - Zambia

Dr. J. Odera

Chief Research Scientist, Kenya Forestry Research Institute (KEFRI)

Nairobi - Kenya

Mrs. Elieen Omosa

Regional Network Coordinator, Forest Action Network (FAN)

Nairobi - Kenya 
Dr. Manuel Ruiz Pérez

CIFOR

Bogor - Indonesia

Prof. A. Temu

ICRAF

Nairobi - Kenya 